\title{
Steroid Sulfatase Inhibitor Reduces Proliferation of Ishikawa Endometrial Cancer Cells in Co-Culture Systems
}

\author{
Mitsuo Nishimoto1,2, Masafumi Toyoshima', Naomi Shiga1, Hiroki Utsunomiya ${ }^{1}$, Fumihiko Suzuki', \\ Satoru Nagase ${ }^{1,3}$, Hidekazu Nishigori' ${ }^{1}$ Takashi Suzuki ${ }^{4}$, Hironobu Sasano4, Kiyoshi Ito5, \\ Nobuo Yaegashi ${ }^{1}$ \\ ${ }^{1}$ Department of Obstetrics and Gynecology, Tohoku University School of Medicine, Sendai, Japan \\ ${ }^{2}$ Department of Obstetrics and Gynecology, Iwate Prefectural Iwai Hospital, Iwate, Japan \\ ${ }^{3}$ Department of Obstetrics and Gynecology, Yamagata University School of Medicine, Yamagata, Japan \\ ${ }^{4}$ Department of Pathology, Tohoku University School of Medicine, Sendai, Japan \\ ${ }^{5}$ Department of Disaster Obstetrics and Gynecology, International Research Institute of Disaster Science, Tohoku University, Sendai, \\ Japan \\ Email:m-toyo@med.tohoku.ac.jp
}

How to cite this paper: Nishimoto, M., Toyoshima, M., Shiga, N., Utsunomiya, H., Suzuki, F., Nagase, S., Nishigori, H., Suzuki, T., Sasano, H., Ito, K. and Yaegashi, N. (2016) Steroid Sulfatase Inhibitor Reduces Proliferation of Ishikawa Endometrial Cancer Cells in Co-Culture Systems. Open Journal of Endocrine and Metabolic Diseases, 6, 193-204.

http://dx.doi.org/10.4236/ojemd.2016.69025

Received: August 21, 2016

Accepted: September 13, 2016

Published: September 16, 2016

Copyright $\odot 2016$ by authors and Scientific Research Publishing Inc. This work is licensed under the Creative Commons Attribution International License (CC BY 4.0).

http://creativecommons.org/licenses/by/4.0/

(c) (i) Open Access

\section{Abstract}

Objectives: Estrogens significantly contribute toward the growth and development of endometrial cancers. Two principal pathways have been implicated in the final steps of estrogen synthesis: the steroid sulfatase (STS) and aromatase pathways. In this study, we aimed to evaluate the possible effects of tumor-stromal interactions on local estrogen biosynthesis in endometrial cancer. We also assessed the biological effects of inhibitors of steroid sulfatase and aromatase in the co-culture system compared with usual monocultures. Methods/Materials: We isolated stromal cells from endometrial cancer patients to examine local biosynthesis of estrogens and tumor-stromal interactions. Next we examined the effects of steroid sulfatase inhibitor and aromatase inhibitor in monoculture of endometrial cancer cell line (Ishikawa) and in a co-culture system involving an Ishikawa cells and stromal cells. Results: Estrogen receptor and steroid sulfatase mRNA levels in cancer cells were significantly higher in the co-cultures compared with the monocultures of endometrial cancer cells. Estradiol and androstenediol concentrations were also significantly higher in the co-cultured cells. Proliferation of the cancer cells was significantly increased through the steroid sulfatase pathway, which metabolizes androgens, estrone sulfate, and estradiol sulfate as its substrates. However, its proliferation was significantly decreased by the treatment of steroid sulfatase or aromatase inhibitors. The significant growth inhibition by the steroid sulfatase and aromatase inhibitors were also observed in the co-culture system. Conclusions: We evaluated the effects of STS inhibitor and aromatase inhibitors on the proliferation 
of estrogen-dependent endometrial cancer cells. Considering that intratumoral estrogen metabolism plays an important role, our co-culture systems provide an environment similar to that of the tumor in living patients in terms of metabolism and synthesis of intratumoral estrogens. The results of this study may aid in achieving improved clinical responses from patients treated with STS inhibitors.

\section{Keywords}

Aromatase Inhibitors, Co-Culture System, Endometrial Cancer, Estrogen, Estrogen Sulfatase Inhibitor

\section{Introduction}

The incidence of endometrial cancer has increased rapidly, and it is now one of the most common gynecologic malignancies in developed countries [1]. It is a paradox that most endometrial cancers are diagnosed in menopausal women, who have low concentrations of circulating estrogen, despite the estrogen dependency in many of endometrial cancer cells [1]. Several studies have focused on intratumoral estrogen metabolism and biosynthesis and reported that estradiol (E2), estrone (E1), and testosterone levels are several times higher in tumor tissues than in serum [2]-[4]. This finding indicates that in situ estrogen metabolism, including its biosynthesis and degradation, plays a very important role in the development of endometrial proliferative disorders, such as endometrial hyperplasia [5], and in furthering the progression to endometrial cancer [2] [3] [6]-[13].

Two principal pathways, the aromatase and steroid sulfatase (STS) pathways, have been implicated in the critical steps of estrogen biosynthesis (reviewed in Figure 1). The enzyme $17 \beta$-hydroxysteroid dehydrogenase (17 $\beta$-HSD) catalyzes the reversible interconversion of E1 and E2. There are two subtypes of $17 \beta$-HSD: type 1 catalyzes E1 to E2, and type 2 preferentially catalyzes the oxidation of E2 to E1 [3] [4] [14]. STS is widely expressed in many organs and responsible for the hydrolysis of dehydroepiandrosterone sulfate (DHEAS), estrone sulfate (E1S), and estradiol sulfate (E2S) into their unconjugated forms. E1S, E2S and DHEAS are the major circulating forms of plasma estrogens and androgens. They are the biologically inactive forms of steroids and have relatively long half-lives in peripheral blood. In breast cancer, it has been reported that in situ estrogen activity may be regulated primarily by intratumoral STS [15] [16].

Furthermore, estrogen signals in tumor cells are greatly affected by their interaction with stromal cells in vivo. Although STS and Estrogen sulfotransferase (EST) activities have been examined in estrogen-dependent neoplasms [17] [18], STS-mediated regulation of tumor-stromal interactions has not been elucidated fully. We previously established a co-culture system involving an endometrial cancer cell line and primary cultured stromal cells [19] [20]. In this study, we aimed to evaluate the possible effects of tumor-stromal interactions on local estrogen biosynthesis in endometrial cancer and to assess the biological effects of inhibitors of STS and aromatase in the co-culture system compared with usual monocultures. 


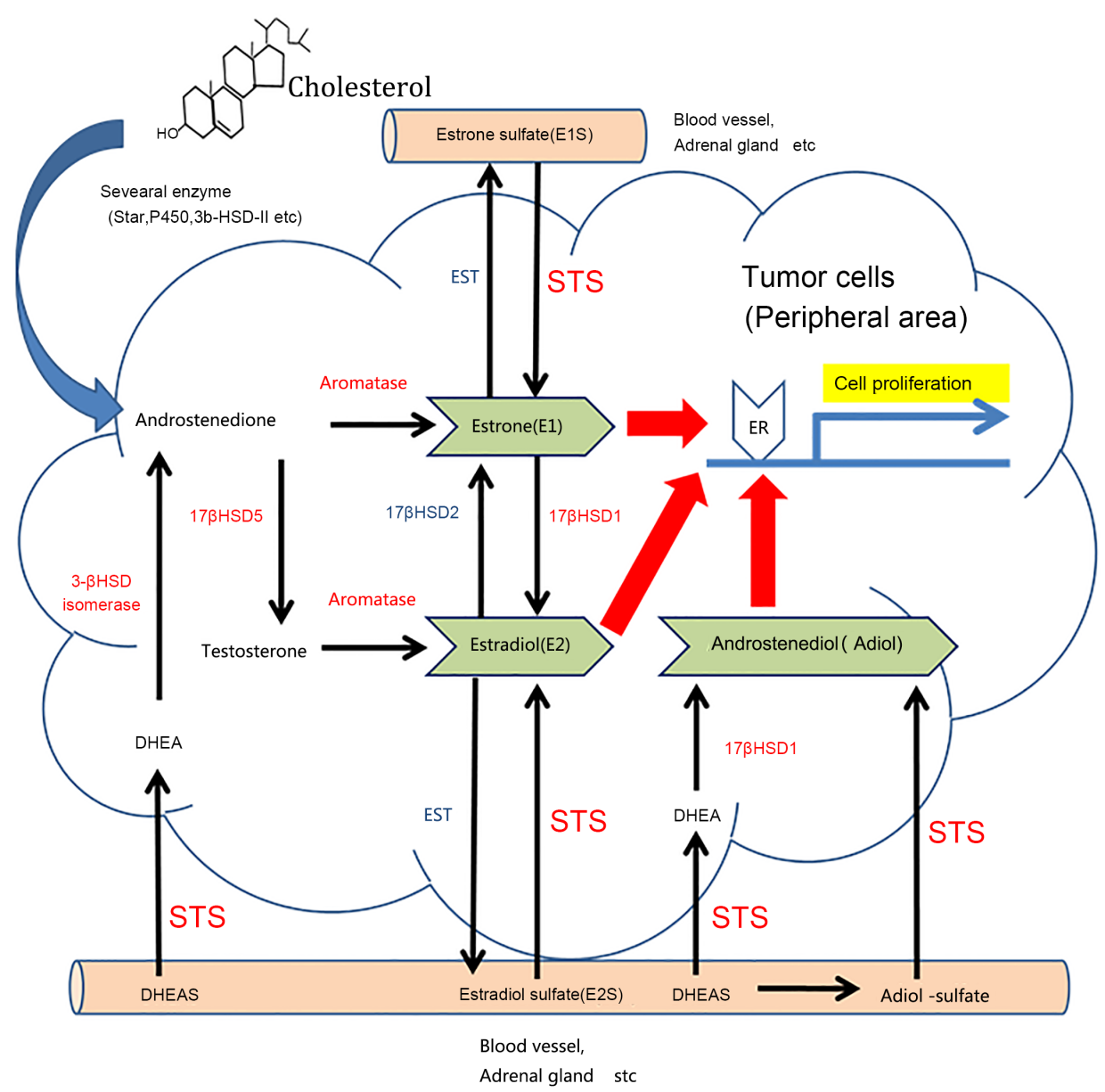

Figure 1. The sketch of the intratumoral estrogen production. Two principal pathways, steroid sulfatase (STS) pathway and aromatase pathway are implicated in the crucial steps of estrogen synthesis. The enzyme $17 \beta$-hydroxysteroid dehydrogenase (17 $\beta$-HSD) catalyzes reversible interconversion of E1 and E2. STS is responsible for the hydrolysis of dehydroepiandrosterone sulfate (DHEAS), Androstenediol (Adiol)-sulfate, estrone sulfate (E1S), and estradiol sulfate (E2S) into their unconjugated forms. Estrogen sulfotransferase (EST) is a member of the superfamily of steroid-sulfotransferases and sulfonates estrogens to estrogen sulfates. DHEAS also converts to Adiol-sulfate, but the contribution of this pathway remains to be unresolved. Adiol also binds to the estrogen receptor (ER) although Adiol is androgen.

\section{Materials and Methods}

\subsection{Tissue Preparation and Cell Culture Conditions}

This study was approved by the Ethics Committee of Tohoku University School of Medicine, Sendai, Japan (No. 2009-75), and the required informed consent forms were obtained. We isolated stromal cells from three patients who underwent hysterectomy under the diagnosis as endometrial cancer at the Department of Obstetrics and Gynecology in Tohoku University Hospital, Sendai, Japan. The pathological diagnosis was endometrioid adenocarcinoma in all cases. All of the examined patients had not received irradiation or chemotherapy prior to surgery. The procedures used to isolate stromal cells have been described previously [19] [21]. The human endometrial cancer 
cell line Ishikawa, which is a representative estrogen-dependent cell line of endometrial cancer, was kindly provided by Dr. Nishida (Tokyo Medical University Kasumigaura Hospital, Ibaragi, Japan). These cells were maintained in DMEM/F12 supplemented with $10 \%$ FBS, antibiotic-antimycotic solution $(100 \mu \mathrm{g} / \mathrm{ml})$, and GlutaMAXTM $(100 \mu \mathrm{g} / \mathrm{ml})$.

\subsection{Co-Culture System}

To separate stromal cells and endometrial cancer cells physically, transwell cultures were established in 6-well plates using Transwell permeable supports $(0.4-\mu \mathrm{m}$ pore size; Corning Incorporated, Corning, NY, USA). First, Ishikawa cells and tumor-derived stromal cells were cultured separately in $100-\mathrm{mm}$ dishes until they reached approximately $80 \%$ confluency. Second, Ishikawa cells $\left(4 \times 10^{4} / \mathrm{ml}\right)$ were cultured in transwell chambers either with or without stromal cells $\left(6 \times 10^{4} / \mathrm{ml}\right)$, which were seeded at the bottom of the 6-well plates. We designated this as the co-culture system, as described previously [19] [20] [22]. The culture medium used was 10\% phenol red-free DMEM/ F12 supplemented with 10\% dextran-coated charcoal-treated FBS (DCC-FBS). Finally, after $72 \mathrm{~h}$ of co-culturing, Ishikawa and stromal cells were separated again, and each cell type was examined by real-time quantitative RT-PCR, a hormone production assay, and a cell proliferation assay.

\subsection{RNA Extraction, cDNA Synthesis, and Real-Time RT-PCR}

RNA extraction was performed using ISOGEN II (Nippon Gene Co. Ltd, Saitama, Japan). To synthesize cDNA, we used the QuantiTect Reverse Transcription Kit (Qiagen, Co. Ltd, Tokyo, Japan). Both procedures were performed per the manufacturers' protocols. Real-time RT-PCR was performed using the Taq Man method (Applied Biosystems by Life Technologies, Tokyo, Japan) with the following thermal cycler parameters: 40 amplification cycles at $95^{\circ} \mathrm{C}$ for $15 \mathrm{~s}$ and $60^{\circ} \mathrm{C}$ for $60 \mathrm{~s}$. The primers used in this study were designed against GAPDH (Hs02758991), ER $\alpha$ (00174860), and STS (NM0096676). To quantify the target cDNA amplicons, known cDNA amounts of the target genes and the GAPDH housekeeping gene were used to generate standard curves for real-time RT-PCR. Target mRNA levels were expressed relative to the GAPDH mRNA level.

\subsection{Hormone Production Assay Using Liquid Chromatography-Tandem Mass Spectrometry (LC-MS/MS)}

To determine the potential effects of tumor-stromal interactions on local hormone biosynthesis in endometrial cancer, E2 and androstenediol concentrations in both co-culture and monoculture systems were determined by LC-MS/MS analysis at ASKA Pharma Medical, as described previously [20] [23]. All cells were treated with DHEAS (10 - 5 mol/l; Sigma-Aldrich, Co., Ltd, Tokyo, Japan), used as the substrate, for $72 \mathrm{~h}$ and were quantified by the trypan blue exclusion method. E2 and androstenediol concentrations in the absence of cells were used as controls.

\subsection{Cell Proliferation Assay}

Ishikawa cells $\left(2 \times 10^{4} / \mathrm{ml}\right)$ were seeded in phenol red-and FBS-free DMEM/F12 me- 
dium in 96-well plates. After $16 \mathrm{~h}$ of starvation, the culture medium was exchanged with DCC-FBS DMEM/F12 medium, and E1S (10 - 7 mol/l; Sigma-Aldrich), E2S (10 - 7 mol/l; Sigma-Aldrich), DHEAS (10 - $5 \mathrm{~mol} / \mathrm{l}$; Sigma-Aldrich), a STS inhibitor (STX64; 10 - $7 \mathrm{~mol} / \mathrm{l}$; Sigma-Aldrich), or aromatase inhibitors (letrozole, 10 - $7 \mathrm{~mol} / \mathrm{l}$; exemestane, 10 - 7 mol/l; Sigma-Aldrich) were added, as described previously [15] [24]. Cell proliferation was assessed using the WST method (Cell Counting Kit-8; Dojindo Molecular Technologies, Kumamoto, Japan) at 8 days. After co-culture with stromal cells for $72 \mathrm{~h}$, Ishikawa cells $\left(2 \times 10^{4}\right.$ cells $\left./ \mathrm{ml}\right)$ were trypsinized and seeded in 96-well plates in DCC-FBC DMEM/F12 medium. After $24 \mathrm{~h}$, we added substrate to each well. After $16 \mathrm{~h}$ of starvation, the culture medium was exchanged with DCC-FBS DMEM/F12 medium, and DHEAS (10 - $5 \mathrm{~mol} / \mathrm{l})$, the STS inhibitor STX64 $(10-7 \mathrm{~mol} / \mathrm{l})$, or the aromatase inhibitors letrozole $(10-7 \mathrm{~mol} / \mathrm{l})$ and exemestane $(10-7 \mathrm{~mol} / \mathrm{l})$ were added. Cell proliferation was assessed by WST assay at 6 and 8 days.

\subsection{Statistical Analysis}

The results from the two groups were compared by Student's t-test using the JMP Pro 9 software program (SAS Institute Inc., Tokyo, Japan).

\section{Results}

\subsection{ER $\alpha$ and STS mRNA Expression Levels in Cell Monocultures and Co-Cultures}

We examined ER $\alpha$ and STS expression in Ishikawa cells using the monoculture and co-culture systems. For the co-culture system, we used three independent stromal cell lines, which were isolated from each patient. Average ER $\alpha$ and STS expression levels (Figure 2(a) and Figure 2(b), respectively) in the co-culture system were significantly higher than those in the monocultures. There was no significant difference among the stromal cells regardless of their original epithelial differentiation stage.

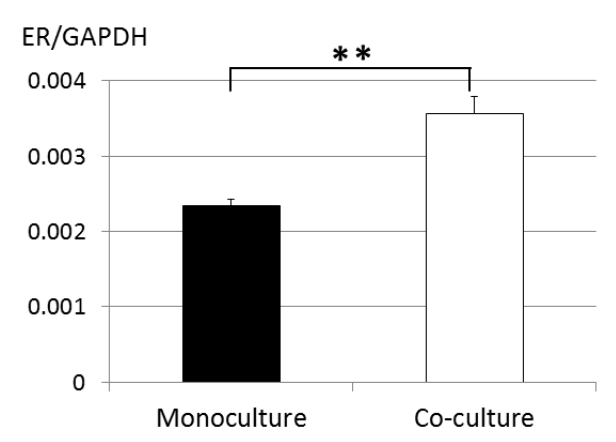

(a)

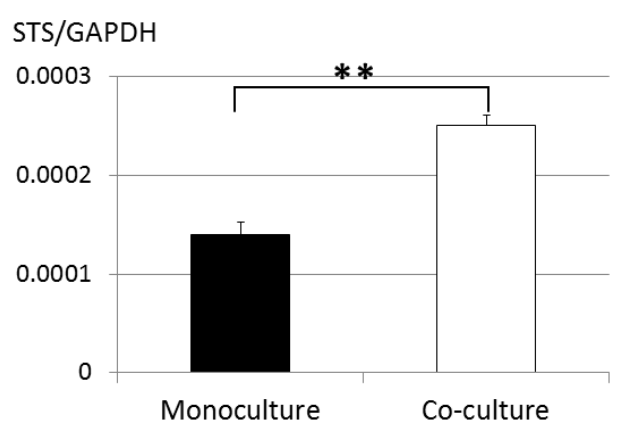

(b)

Figure 2. ER $\alpha$ and STS mRNA expression levels in cell monoculture and co-culture systems. To evaluate the possible effects of tumor-stromal interactions, we examined ER $\alpha$ (a) and STS (b) expression in Ishikawa cells using monoculture and co-culture systems. Representative results from three independent experiments are shown. ${ }^{\star *} \mathrm{P}<0.01$. 


\subsection{E2 and Androstenediol Concentrations in DHEAS-Treated Cells}

To determine the potential effects of tumor-stromal interactions on local estrogen biosynthesis in endometrial cancer, we measured E2 and androstenediol concentrations in the co-cultures and monocultures using LC-MS/MS. Significantly high concentrations of E2 and androstenediol were produced in the co-cultures compared with the monocultures (Figure 3(a) and Figure 3(b), respectively).

\subsection{Cell Proliferation Assays in the Monocultures}

To estimate the inhibitory effects of an STS inhibitor on endometrial cancer growth, we first performed a cell proliferation assay using the monocultured cells and the STS inhibitor, STX64. Cell proliferation was significantly induced after addition of E1S and E2S together or DHEAS, as the substrates; however, this effect was completely prevented by treatment with STX64 (Figure 4(a) and Figure 4(b), respectively). Then, we performed cell proliferation assays after treatment with STX64 or the aromatase inhibitors letrozole and exemestane to determine which form of inhibition was more effective for inhibiting endometrial cancer cell growth. Each inhibitor inhibited cell proliferation to the same extent when only DHEAS was used as the substrate Figure 4(c). However, when E1S and E2S were added together with DHEAS, inhibition of cell growth by the STS inhibitor was much stronger than that by the aromatase inhibitor Figure 4(d).

\subsection{Cell Proliferation Assays in the Co-Culture System}

We next employed co-culture systems using Ishikawa and stromal cells. Cells were treated with STX64 and aromatase inhibitors. Significant cell proliferation was induced after adding DHEAS as the substrate, while it was inhibited significantly by both STX64 and aromatase inhibitors, to the same extent Figure 5.

\section{Discussion}

High-dose progestin is currently the main hormonal therapeutic drug of choice used for

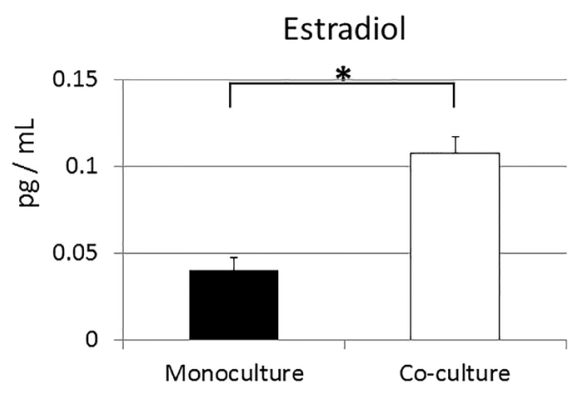

(a)

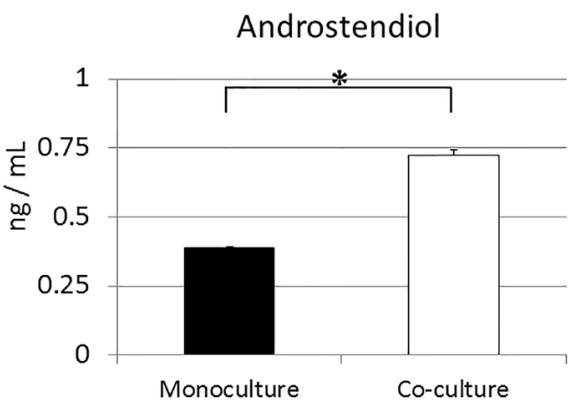

(b)

Figure 3. E2 and androstenediol concentrations in cells treated with DHEAS as the substrate. To estimate the possible effects of tumor-stromal interactions on local estrogen biosynthesis in endometrial cancer, we measured E2 (a) and androstenediol (b) concentrations in co-culture and monoculture systems using LC-MS/MS. We used DHEAS (10 - $5 \mathrm{~mol} / \mathrm{l})$ as the substrate. ${ }^{\star} \mathrm{P}<0.05$. 


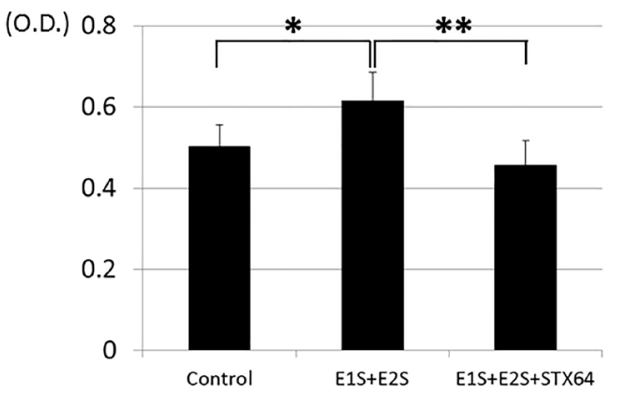

(a)

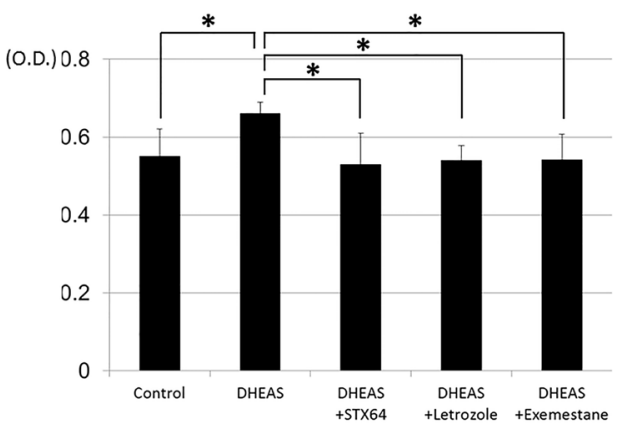

(c)

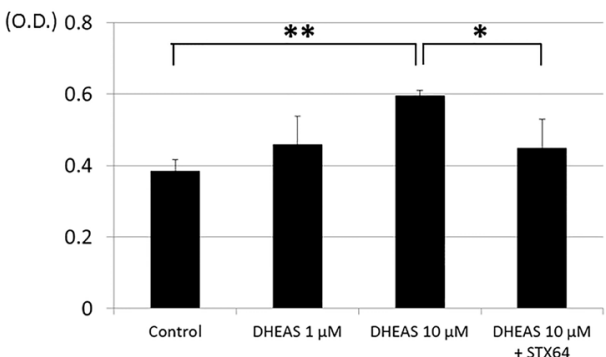

(b)

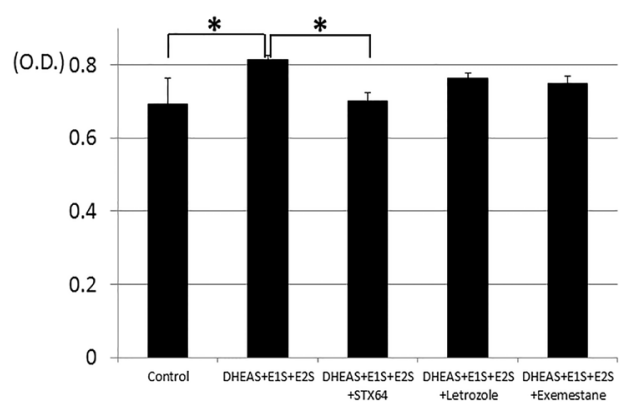

(d)

Figure 4. Cell proliferation assays in a monoculture system. We performed cell proliferation assays to estimate the effects of the substrates E1S and E2S (a) or DHEAS (b) with or without STS inhibitor on endometrial cancer growth. We also compared the cell proliferation in the presence of a STS or aromatase inhibitor to determine which inhibitor was more effective in inhibiting endometrial cancer growth (c) (d). Ishikawa cells $\left(2 \times 10^{4} / \mathrm{ml}\right)$ were seeded in 96-well plates for 16 h. After starvation, E1S (10 - $7 \mathrm{~mol} / \mathrm{l})$, E2S (10 - $7 \mathrm{~mol} / \mathrm{l})$, DHEAS (10 - $5 \mathrm{~mol} / \mathrm{l})$, a STS inhibitor (STX64; 10 - $7 \mathrm{~mol} / \mathrm{l}$ ), or aromatase inhibitors (letrozole, 10 - $7 \mathrm{~mol} / \mathrm{l}$; exemestane, 10 - $7 \mathrm{~mol} / \mathrm{l}$ ) were added. Cell proliferation was assessed using the WST method at 8 days. Representative results from three independent experiments are shown. ${ }^{\star} \mathrm{P}<0.05,{ }^{* *} \mathrm{P}<0.01$.

endometrial cancer treatment, but its response rate is relatively limited [25] [26]. An aromatase localization study demonstrated that aromatase immunoreactivity and mRNA were detected mainly in the stromal cells or fibroblasts of endometrial cancer tissue, but not in normal or hyperplastic endometrium [27]. Aromatase inhibitors are widely used for breast cancer patients as endocrine therapy, but their therapeutic value for endometrial cancer has been reported to have only small or minimal effects [28] [29]. Here, we focused attention on in situ estrogen metabolism in endometrial cancer and employed a co-culture system to evaluate the biological significance of STS and aromatase inhibitors in the presence of tumor-stromal interactions.

STS inhibitor has been previously reported as a potential novel endocrine treatment for breast cancer [4] [30]-[34], with a phase I trial reporting it as safe and promising [35]. We previously demonstrated that increased STS and decreased EST expression levels resulted in increased in situ estrogen activity in endometrial cancers, and there was a significant correlation between the STS/EST expression ratio and the clinical outcomes of these patients [18]. STS inhibitors affect the STS pathway, which is responsi- 


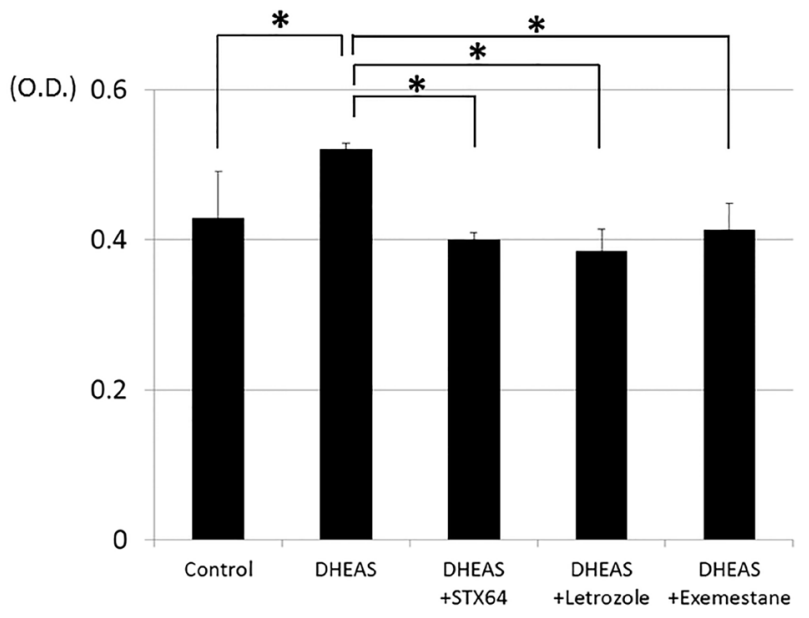

Figure 5. Cell proliferation assays in co-culture systems. After coculturing with stromal cells for $72 \mathrm{~h}$, Ishikawa cells $\left(2 \times 10^{4} / \mathrm{ml}\right)$ were trypsinized and seeded in 96-well plates in DCC-FBC DMEM/ F12 medium. After $24 \mathrm{~h}$, we added substrate to each well. Cell proliferation was assessed by WST assay at 6 and 8 days. Representative results from three independent experiments are shown. ${ }^{*} \mathrm{P}<0.05$.

ble for hydrolysis of E1S, E2S, DHEAS and adiol-sulfate into their unconjugated forms. E1S, E2S and DHEAS are the major circulating forms of plasma estrogens and androgen, respectively. They are biologically inactive steroid forms that have relatively long half-lives in peripheral blood [24] [36] [37]. DHEAS and its unconjugated metabolite, dehydroepiandrosterone (DHEA), serve as precursors for the formation of steroids with estrogenic properties, such as E2 and androstenediol [38]. In fact, DHEAS, DHEA, and androstenediol stimulated the proliferation of breast cancer cells in vitro and induced mammary tumors in vivo [38]. In postmenopausal women, the major source of androstenediol is derived from DHEAS and DHEA in peripheral tissues. It has been reported that androstenediol, although an androgen, can bind to ER $\alpha$, and that androstenediol can stimulate the proliferation of ER $\alpha+$ breast cancer cells and induce mammary tumors in vivo [38]. Co-incubation of DHEAS with aromatase inhibitors did not block its ability to activate ER $\alpha+$ breast cancer cells [38].

In this study, we employed a co-culture system to obtain important information regarding the intratumoral microenvironment. ER $\alpha$ and STS expression levels in our co-culture system were significantly higher than those in the monoculture of endometrial cancer cells, and significantly more E2 and androstenediol were produced in the co-cultures compared with the monocultures. To evaluate the efficacy of STS and aromatase inhibitors for endometrial cancer, we examined cell proliferation in the presence of the substrates E1S, E2S and DHEAS.

There are some limitations in our study. First, we used only one cell line type, Ishikawa cells in this study. Although Ishikawa is a representative estrogen-dependent endometrial cancer cell line, those cancers have an over $90 \% 5$ year survival rate and not 
often recur or cause metastasis. Expansion of the effects of SDS inhibitors on more cells lines with different estrogen dependency will benefit patients with endometrial cancer. Second, it is unclear how much co-cultures can reflect the real tumor micro-environment. However, we think our results indicate that STS inhibitors might be a novel treatment of option for endometrial cancer in addition to aromatase inhibitors, particularly for postmenopausal women in whom intratumoral estrogen metabolism plays an important role. The expression of those enzymes needs careful consideration, and personalized treatment regimens may be needed. Further investigation is needed to elucidate their role in endometrial cancer.

\section{Conclusion}

In conclusion, we evaluated the effects of STS inhibitor and aromatase inhibitors on the proliferation of estrogen-dependent endometrial cancer cells. Considering that intratumoral estrogen metabolism plays an important role, our co-culture systems provide an environment similar to that of the tumor in living patients in terms of metabolism and synthesis of intratumoral estrogens. The results of this study may aid in achieving improved clinical responses from patients treated with STS inhibitors.

\section{Acknowledgements}

This study was supported in part by a 1) Grant-in-Aid for Exploratory Research, from the Ministry of Education, Science, Sports and Culture, Japan (23791802), 2) Research Promotion and Practical Use for Women's Health, AMED.

\section{References}

[1] Siegel, R., Naishadham, D. and Jemal, A. (2012) Cancer Statistics, 2012. CA: A Cancer Journal for Clinicians, 62, 10-29. http://dx.doi.org/10.3322/caac.20138

[2] Berstein, L.M., Tchernobrovkina, A.E., Gamajunova, V.B., Kovalevskij, A.J., Vasilyev, D.A., Chepik, O.F., et al. (2003) Tumor Estrogen Content and Clinico-Morphological and Endocrine Features of Endometrial Cancer. Journal of Cancer Research and Clinical Oncology, 129, 245-249.

[3] Ito, K., Utsunomiya, H., Niikura, H., Yaegashi, N. and Sasano, H. (2011) Inhibition of Estrogen Actions in Human Gynecological Malignancies: New Aspects of Endocrine Therapy for Endometrial Cancer and Ovarian Cancer. Molecular and Cellular Endocrinology, 340, 161-167.

[4] Bulun, S.E., Lin, Z., Imir, G., Amin, S., Demura, M., Yilmaz, B., et al. (2005) Regulation of Aromatase Expression in Estrogen-Responsive Breast and Uterine Disease: From Bench to Treatment. Pharmacological Reviews, 57, 359-383. http://dx.doi.org/10.1124/pr.57.3.6

[5] Adessi, G.L., Prost, O., Agnani, G., Petitjean, A. and Burnod, J. (1984) Estrone Sulfatase Activity in Normal and Abnormal Endometrium. Archives of Gynecology, 236, 13-18.

http://dx.doi.org/10.1007/BF02114864

[6] Bonney, R.C., Scanlon, M.J., Jones, D.L., Reed, M.J., Anderson, M.C. and James, V.H. (1986) The Relationship between Oestradiol Metabolism and Adrenal Steroids in the Endometrium of Postmenopausal Women with and without Endometrial Cancer. European Journal of Cancer and Clinical Oncology, 22, 953-961. 
http://dx.doi.org/10.1016/0277-5379(86)90062-3

[7] Tseng, L., Mazella, J., Mann, W.J. and Chumas, J. (1982) Estrogen Synthesis in Normal and Malignant Human Endometrium. The Journal of Clinical Endocrinology \& Metabolism, 55, 1029-1031. http://dx.doi.org/10.1210/jcem-55-5-1029

[8] Cornel, K.M.C., Kruitwagen, R.F.P.M., Delvoux, B., Visconti, L., Van de Vijver, K.K., Day, J.M., et al. (2012) Overexpression of $17 \beta$-Hydroxysteroid Dehydrogenase Type 1 Increases the Exposure of Endometrial Cancer to $17 \beta$-Estradiol. The Journal of Clinical Endocrinology \& Metabolism, 97, E591-E601. http://dx.doi.org/10.1210/jc.2011-2994

[9] Hevir, N., Sinkovec, J. and Rižner, T.L. (2011) Disturbed Expression of Phase I and Phase II Estrogen-Metabolizing Enzymes in Endometrial Cancer: Lower Levels of CYP1B1 and Increased Expression of S-COMT. Molecular and Cellular Endocrinology, 331, 158-167.

[10] Jongen, V.H.W.M., Briët, J.M., de Jong, R.A., Joppe, E., ten Hoor, K.A., Boezen, H.M., et al. (2009) Aromatase, Cyclooxygenase 2, HER-2/neu, and p53 as Prognostic Factors in Endometrioid Endometrial Cancer. International Journal of Gynecological Cancer, 19, 670-676. http://dx.doi.org/10.1111/IGC.0b013e3181a47c25

[11] Pathirage, N., Di Nezza, L.A., Salmonsen, L.A., Jobling, T., Simpson, E.R. and Clyne, C.D. (2006) Expression of Aromatase, Estrogen Receptors, and Their Coactivators in Patients with Endometrial Cancer. Fertility Sterility, 86, 469-472. http://dx.doi.org/10.1016/j.fertnstert.2005.12.057

[12] Sinreih, M., Hevir, N. and Rižner, T.L. (2013) Altered Expression of Genes Involved in Progesterone Biosynthesis, Metabolism and Action in Endometrial Cancer. Chemico-Biological Interactions, 202, 210-217. http://dx.doi.org/10.1016/j.cbi.2012.11.012

[13] Smuc, T. and Rizner, T.L. (2009) Aberrant Pre-Receptor Regulation of Estrogen and Progesterone Action in Endometrial Cancer. Molecular and Cellular Endocrinology, 301, 74-82. http://dx.doi.org/10.1016/j.mce.2008.09.019

[14] Moeller, G. and Adamski, J. (2009) Integrated View on 17beta-Hydroxysteroid Dehydrogenases. Molecular and Cellular Endocrinology, 301, 7-19. http://dx.doi.org/10.1016/j.mce.2008.10.040

[15] Suzuki, T., Nakata, T., Miki, Y., Kaneko, C., Moriya, T., Ishida, T., et al. (2003) Estrogen Sulfotransferase and Steroid Sulfatase in Human Breast Carcinoma. Cancer Research, 63, 2762-2770.

[16] Utsumi, T., Yoshimura, N., Takeuchi, S., Maruta, M., Maeda, K. and Harada, N. (2000) Elevated Steroid Sulfatase Expression in Breast Cancers. Journal of Steroid Biochemistry and Molecular Biology, 73, 141-145. http://dx.doi.org/10.1016/S0960-0760(00)00060-1

[17] Suzuki, T., Miki, Y., Nakamura, Y., Ito, K. and Sasano, H. (2011) Steroid Sulfatase and Estrogen Sulfotransferase in Human Carcinomas. Molecular and Cellular Endocrinology, 340, 148-153. http://dx.doi.org/10.1016/j.mce.2010.11.001

[18] Utsunomiya, H., Ito, K., Suzuki, T., Kitamura, T., Kaneko, C., Nakata, T., et al. (2004) Steroid Sulfatase and Estrogen Sulfotransferase in Human Endometrial Carcinoma. Clinical Cancer Research, 10, 5850-5856. http://dx.doi.org/10.1158/1078-0432.CCR-04-0040

[19] Yamaguchi, Y., Takei, H., Suemasu, K., Kobayashi, Y., Kurosumi, M., Harada, N., et al. (2005) Tumor-Stromal Interaction through the Estrogen-Signaling Pathway in Human Breast Cancer. Cancer Research, 65, 4653-4562. http://dx.doi.org/10.1158/0008-5472.CAN-04-3236

[20] Takahashi-Shiga, N., Utsunomiya, H., Miki, Y., Nagase, S., Kobayashi, R., Matsumoto, M., et al. (2009) Local Biosynthesis of Estrogen in Human Endometrial Carcinoma through tumor-Stromal Cell Interactions. Clinical Cancer Research, 15, 6028-6034. 
http://dx.doi.org/10.1158/1078-0432.CCR-09-1013

[21] Miki, Y., Suzuki, T., Tazawa, C., Yamaguchi, Y., Kitada, K., Honma, S., et al. (2007) Aromatase Localization in Human Breast Cancer Tissues: Possible Interactions between Intratumoral Stromal and Parenchymal Cells. Cancer Research, 67, 3945-3954. http://dx.doi.org/10.1158/0008-5472.CAN-06-3105

[22] Matsumoto, M., Yamaguchi, Y., Seino, Y., Hatakeyama, A., Takei, H., Niikura, H., et al. (2008) Estrogen Signaling Ability in Human Endometrial Cancer through the Cancer-Stromal Interaction. Endocrine-Related Cancer, 15, 451-463. http://dx.doi.org/10.1677/ERC-07-0227

[23] Suzuki, T., Miki, Y., Moriya, T., Akahira, J., Ishida, T., Hirakawa, H., et al. (2007) 5AlphaReductase Type 1 and Aromatase in Breast Carcinoma as Regulators of in Situ Androgen Production. International Journal of Cancer, 120, 285-291.

http://dx.doi.org/10.1002/ijc.22317

[24] Lukanova, A., Lundin, E., Micheli, A., Arslan, A., Ferrari, P., Rinaldi, S., et al. (2004) Circulating Levels of Sex Steroid Hormones and Risk of Endometrial Cancer in Postmenopausal Women. International Journal of Cancer, 108, 425-432. http://dx.doi.org/10.1002/ijc.11529

[25] Thigpen, J.T., Brady, M.F., Alvarez, R.D., Adelson, M.D., Homesley, H.D., Manetta, A., et al. (1999) Oral Medroxyprogesterone Acetate in the Treatment of Advanced or Recurrent Endometrial Carcinoma: A Dose-Response Study by the Gynecologic Oncology Group. Journal of Clinical Oncology, 17, 1736-1744.

[26] Ushijima, K., Yahata, H., Yoshikawa, H., Konishi, I., Yasugi, T., Saito, T., et al. (2007) Multicenter Phase II Study of Fertility-Sparing Treatment with Medroxyprogesterone Acetate for Endometrial Carcinoma and Atypical Hyperplasia in Young Women. Journal of Clinical Oncology, 25, 2798-2803. http://dx.doi.org/10.1200/JCO.2006.08.8344

[27] Watanabe, K., Sasano, H., Harada, N., Ozaki, M., Niikura, H., Sato, S., et al. (1995) Aromatase in Human Endometrial Carcinoma and Hyperplasia. Immunohistochemical, in Situ Hybridization, and Biochemical Studies. American Journal of Pathology, 146, 491-500.

[28] Ma, B.B.Y., Oza, A., Eisenhauer, E., Stanimir, G., Carey, M., Chapman, W., et al. (2004) The Activity of Letrozole in Patients with Advanced or Recurrent Endometrial Cancer and Correlation with Biological Markers-A Study of the National Cancer Institute of Canada Clinical Trials Group. International Journal of Gynecological Cancer, 14, 650-658. http://dx.doi.org/10.1111/j.1048-891X.2004.14419.x

[29] Rose, P.G., Brunetto, V.L., VanLe, L., Bell, J., Walker, J.L. and Lee, R.B. (2000) A Phase II Trial of anastrozole in Advanced Recurrent or Persistent Endometrial Carcinoma: A Gynecologic Oncology Group Study. Gynecologic Oncology, 78, 212-216. http://dx.doi.org/10.1006/gyno.2000.5865

[30] Foster, P.A., Chander, S.K., Newman, S.P., Woo, L.W.L., Sutcliffe, O.B., Bubert, C., et al. (2008) A New Therapeutic Strategy against Hormone-Dependent Breast Cancer: The Preclinical Development of a Dual Aromatase and Sulfatase Inhibitor. Clinical Cancer Research, 14, 6469-6477. http://dx.doi.org/10.1158/1078-0432.CCR-08-1027

[31] Ishida, H., Nakata, T., Suzuki, M., Shiotsu, Y., Tanaka, H., Sato, N., et al. (2007) A Novel Steroidal Selective Steroid Sulfatase Inhibitor KW-2581 Inhibits Sulfated-Estrogen Dependent Growth of Breast Cancer Cells in Vitro and in Animal Models. Breast Cancer Research and Treatment, 106, 215-227. http://dx.doi.org/10.1007/s10549-007-9495-x

[32] Ishida, H., Sato, N., Hosogi, J., Tanaka, H. and Kuwabara, T. (2008) Inactivation of Recombinant Human Steroid Sulfatase by KW-2581. Journal of Steroid Biochemistry and Molecular Biology, 108, 17-22. http://dx.doi.org/10.1016/j.jsbmb.2007.06.003

[33] Purohit, A. and Foster, P. (2012) Steroid Sulfatase Inhibitors for Estrogen- and Andro- 
gen-Dependent Cancers. Journal of Endocrinology, 212, 99-110.

http://dx.doi.org/10.1530/JOE-11-0266

[34] Stanway, S.J., Delavault, P., Purohit, A., Woo, L.W.L., Thurieau, C., Potter, B.V.L., et al. (2007) Steroid Sulfatase: A New Target for the Endocrine Therapy of Breast Cancer. Oncologist, 12, 370-374. http://dx.doi.org/10.1634/theoncologist.12-4-370

[35] Stanway, S.J., Purohit, A., Woo, L.W.L., Sufi, S., Vigushin, D., Ward, R., et al. (2006) Phase I Study of STX 64 (667 Coumate) in Breast Cancer Patients: The First Study of a Steroid Sulfatase Inhibitor. Clinical Cancer Research, 12, 1585-1592.

http://dx.doi.org/10.1158/1078-0432.CCR-05-1996

[36] Audet-Walsh, E., Lépine, J., Grégoire, J., Plante, M., Caron, P., Têtu, B., et al. (2011) Profiling of Endogenous Estrogens, Their Precursors, and Metabolites in Endometrial Cancer Patients: Association with Risk and Relationship to Clinical Characteristics. Journal of Clinical Endocrinology \& Metabolism, 96, E330-E339.

http://dx.doi.org/10.1210/jc.2010-2050

[37] Lépine, J., Audet-Walsh, E., Grégoire, J., Têtu, B., Plante, M., Ménard, V., et al. (2010) Circulating Estrogens in Endometrial Cancer Cases and Their Relationship with Tissular Expression of Key Estrogen Biosynthesis and Metabolic Pathways. Journal of Clinical Endocrinology \& Metabolism, 95, 2689-2698. http://dx.doi.org/10.1210/jc.2010-2648

[38] Reed, M.J., Purohit, A., Woo, L.W.L., Newman, S.P. and Potter, B.V.L. (2005) Steroid Sulfatase: Molecular Biology, Regulation, and Inhibition. Endocrine Reviews, 26, 171-202. http://dx.doi.org/10.1210/er.2004-0003

\section{Submit or recommend next manuscript to SCIRP and we will provide best service for you:}

Accepting pre-submission inquiries through Email, Facebook, LinkedIn, Twitter, etc.

A wide selection of journals (inclusive of 9 subjects, more than 200 journals)

Providing 24-hour high-quality service

User-friendly online submission system

Fair and swift peer-review system

Efficient typesetting and proofreading procedure

Display of the result of downloads and visits, as well as the number of cited articles

Maximum dissemination of your research work

Submit your manuscript at: http://papersubmission.scirp.org/ 